\title{
Perilaku Seksual Remaja dan Pengaruh Lingkungan Sosial pada Anak-Anak Keluarga Migran dan Nonmigran
}

\author{
Sri Purwatiningsih \\ Pusat Studi Kependudukan dan Kebijakan, Universitas Gadjah Mada, Yogyakarta \\ Korespondensi: Sri Purwatiningsih (e-mail: athayarafif@yahoo.com)
}

\begin{abstract}
Abstrak
Perilaku seksual pranikah pada remaja merupakan persoalan sosial yang perlu mendapatkan perhatian. Perilaku seksual pranikah ini menjadi masalah karena tidak diimbangi dengan pengetahuan mengenai kesehatan reproduksi yang memadai sehingga sering berakibat terjadinya kehamilan tidak dikehendaki di kalangan remaja. Lingkungan sosial menjadi salah satu faktor yang dapat menjadi faktor pendorong perilaku remaja, tetapi pada sisi yang lain lingkungan sosial dapat melakukan perubahan perilaku. Artikel ini nantinya akan menggambarkan tentang perilaku seksual remaja, baik pada remaja dari keluarga migran maupun nonmigran di daerah penelitian CHAMPSEA (Child Health and Migrant Parents in South East Asia) di Jawa Barat dan Jawa Timur. Responden untuk artikel ini adalah kategori remaja (young adult) dengan sampel sejumlah 429 anak remaja dari rumah tangga migran dan nonmigran. Hasil studi menunjukkan bahwa sebanyak 5,07 persen remaja yang belum menikah telah melakukan hubungan seksual pranikah, yang dilakukan baik oleh remaja dari keluarga migran dan nonmigran. Berdasarkan jenis kelamin, perilaku seksual pranikah lebih banyak dilakukan oleh remaja perempuan dibandingkan dengan remaja laki-laki. Sementara itu, usia pertama kali melakukan hubungan seksual pranikah paling banyak dilakukan oleh remaja yang berusia 18 tahun (35 persen) dan hal ini berbeda dengan persepsi mereka tentang usia menikah. Berdasarkan lingkungan sosial remaja, terdapat 28,74 persen responden yang memiliki teman yang telah melakukan hubungan seksual pranikah, bahkan ada yang menganjurkan dan memaksa responden untuk melakukan hubungan seksual pranikah.
\end{abstract}

Kata kunci: migrasi; migrasi internasional; perilaku remaja; seksual pranikah 


\title{
Adolescent Sexual Behavior and The Effect of The Social Environment among Children of Migran and Non-Migrant Households
}

\begin{abstract}
Premarital sexual behavior in adolescents is a social problem that needs attention. Premarital sexual behavior is problematic, because it is not balanced with adequate knowledge of reproductive health, so it often results in unwanted pregnancies among adolescents. The social environment is one of the factors that can be a driving factor for adolescent behavior, but on the other hand the social environment can also make behavioral changes. This article will describe adolescent sexual behavior, both for adolescents from migrant and non-migrant households in the CHAMPSEA (Child Health and Migrant Parents in South East Asia) research area in West Java and East Java. Respondents for this article are young adults with a sample of 429 adolescents from migrant and non-migrant households. The results of the study show that as many as 5.07 percent of unmarried adolescents have had premarital sexual relations, which are carried out both by adolescents from migrant and non-migrant households. Based on gender, premarital sexual behavior is more often carried out by girls than boys. While the age of first premarital sexual intercourse is mostly carried out by adolescents aged 18 years (35 percent), which is different from their perceptions of the age of marriage. Whereas based on the social environment of adolescents, there are 28.74 percent of respondents who have friends who have premarital sexual relations, some even advocate and force respondents to have premarital sexual relations.
\end{abstract}

Keywords: migration; international migration; adolescent behavior; premarital sex

\section{Latar Belakang}

Perilaku seksual remaja merupakan salah satu permasalahan kesehatan reproduksi pada remaja yang perlu mendapatkan perhatian. Persoalan kesehatan reproduksi padaremaja padaakhirnya dapatmengganggu kualitas remaja. Perilaku seksual remaja yang tidak sehat, misalnya perilaku seksual pranikah yang berisiko, merupakan salah satu persoalan kesehatan reproduksi remaja yang banyak terjadi. Persoalan kesehatan reproduksi remaja menjadi salah satu faktor yang menghambat kualitas kehidupan remaja karena banyak remaja yang terjebak dalam perilaku seksual pranikah (Soetjiningsih, 2004). Pengetahuan remaja yang kurang sering kali menjadi penyebab dari perilaku seksual berisiko yang dilakukan oleh remaja sehingga terkadang berakibat terjadinya kehamilan tidak dikehendaki di kalangan remaja.

Beberapa penelitian terkait dengan kehidupan remaja Indonesia pada umumnya menyimpulkan nilai-nilai hidup remaja sedang dalam proses perubahan, yaitu adanya kecenderungan untuk bertoleransi terhadap gaya hidup seksual pranikah. Data hasil Survei Kesehatan Reproduksi Remaja Indonesia (SKRRI) tahun 2012 menunjukkan bahwa jumlah remaja yang pernah melakukan hubungan seksual pranikah pada usia 15-19 tahun sebanyak 0,7 persen perempuan dan 4,5 persen laki-laki serta sebagian besar bertempat tinggal di perkotaan. Data SDKI, baik data 2007 maupun 2012, secara umum menunjukkan bahwa remaja laki-laki lebih banyak yang mengatakan pernah melakukan 
seks pranikah dibandingkan dengan remaja perempuan. Sementara itu, jika dibandingkan dengan tahun 2007, persentase remaja yang pernah melakukan seks pranikah cenderung meningkat. Alasan melakukan hubungan seksual pranikah tersebut pada remaja lakilaki sebagian besar karena penasaran atau ingin tahu (57,5 persen). Rasa ingin tahu dan coba-coba yang menjadi alasan remaja melakukan hubungan seksual pra nikah juga ditegaskan oleh Holzner dan Utomo (2004). Hal ini menunjukkan terbatasnya pengetahuan mengenai kesehatan reproduksi pada remaja.

Beberapa data menunjukkan bahwa akibat dari kurangnya pengetahuan remaja mengenai kesehatan reproduksi, perilaku seksual remaja semakin meningkat. Hasil penelitian Nasution (2012) menunjukkan rendahnya pengetahuan remaja tentang kesehatan reproduksi, yang pada akhirnya berpengaruh pada perilaku seksual pranikah. Penelitian Purbono, dkk. (2015) juga menunjukkan bahwa pengetahuan remaja tentang kesehatan reproduksi belum baik. Sementara itu, pengetahuan remaja yang tidak memadai dalam hal kesehatan reproduksi dapat mengakibatkan terjadinya perilaku seksual yang berisiko (Scott-Jones dan White, 1990). Rendahnya pengetahuan remaja tentang kesehatan reproduksi lebih banyak disebabkan oleh sumber informasi remaja tidak dapat dipertanggungjawabkan. Remaja justru mendapatkan informasi dari teman dekat atau sebaya, majalah, film, atau video (Hidayana, dkk., 1997).

Lingkungan sosial menjadi salah satu faktor yang dapat menjadi faktor pendorong perilaku remaja, tetapi pada sisi yang lain lingkungan sosial dapat mengubah perilaku. Teman merupakan faktor yang paling memengaruhi perilaku seksual remaja. Teman juga menjadi tempat bagi remaja untuk membicarakan masalah kesehatan reproduksi (Purwatiningsih dan Furi, 2010). Data SKRRI tahun 2012 juga menunjukkan bahwa sekitar 29 persen remaja perempuan dan 48 persen remaja laki-laki memperoleh informasi tentang kesehatan reproduksi dari teman sebaya.

Sebagaimana diketahui, seharusnya keluarga sebagai salah satu lingkungan yang paling dekat dengan remaja dapat berperan dalam perubahan perilaku remaja. Soetjiningsih (2006) menunjukkan makin baik hubungan orang tua dengan anak remajanya akan makin rendah perilaku seksual pranikah remaja. Hal ini karena keluarga merupakan sumber utama pembentukan kepribadian dan penyampaian pesan kesehatan, termasuk kesehatan reproduksi remaja (Effendi dan Makhfudli, 2009).

Keluarga juga dapat sebagai media untuk melakukan upaya promotif dan preventif pada remaha. Namun, pada kalangan keluarga migran, kondisi ini justru menjadi tantangan karena anak-anak yang ditinggalkan akan kehilangan faktor yang seharusnya mampu mencegah perilaku seksual remaja. Oleh karena itu, artikel ini nantinya akan mencoba menggambarkan perilaku seksual remaja, baik pada remaja dari keluarga migran maupun nonmigran di daerah penelitian CHAMPSEA (Child Health and Migrant Parents in South East Asia) di Jawa Barat dan Jawa Timur. Secara khusus, artikel ini bertujuan untuk mengetahui perilaku seksual remaja pada keluarga migran dan nonmigran serta mengetahui peran lingkungan sosial dan keluarga terhadap perilaku seksual remaja.

\section{Lingkungan Sosial yang Melingkupi Seksualitas Remaja}

Sosialisasi dengan lingkungan sosial dibutuhkan oleh remaja untuk menunjukkan eksistensinya. Teman merupakan tempat 
remaja berbagi pengalaman, yang sering tidak mereka dapatkan pada keluarga. Remaja cenderung lebih banyak bertanya kepada teman-temannya dalam hal pergaulan dan masalah seksual (House, dkk., 2003). Oleh karena itu, teman sebaya memiliki peran penting dalam kehidupan sosial dan perkembangan remaja (Rahman, dkk., 2015).

Pergaulantemansebayadapatmemengaruhi perilaku, baik positif naupun negatif. Teman sebaya berperan aktif memberikan informasi mengenai kesehatan reproduksi dan perilaku seksual. Di samping itu, remaja yang memiliki teman sebaya yang telah pernah melakukan hubungan seksual cenderung untuk berperilaku seksual pranikah (Darmayanti, dkk., 2011). Dengan demikian, teman yang berperilaku negatif cenderung akan memberikan pengaruh negatif bagi remaja.

Untuk menjelaskan kaitan antara lingkungan sosial dan remaja, teori Giddens (2003) tentang strukturasi digunakan sebagai rujukan. Teori tersebut menjelaskan bahwa lingkungan sosial merupakan struktur sedangkan remaja merupakan agen. Giddens menganggap bahwa struktur bukan hanya medium, tetapi juga hasil dari tingkah laku (conduct) yang diorganisasikan secara berulang. Dengan kata lain, struktur bukan hanya memandu tindakan, tetapi juga merupakan akibat dari tindakan agent dalam proses produksi dan reproduksi sistem sosial. Remaja sebagai subjek memiliki peran untuk mengontrol struktur. Dengan demikian, antara remaja dan lingkungan sosial saling berkaitan dan saling memengaruhi dalam melakukan tindakan atau perilaku sosial.

Oleh karena itu, keluarga dapat menjadi filter dalam perilaku remaja dari perilaku negatif. Orang tua merupakan salah satu aspek yang sangat penting dalam memengaruhi perilaku remaja (Pearson, 2006). Hasil studi Putri (2014) juga menunjukkan bahwa ada hubungan antara perhatian orang tua dengan perilaku seksual pranikah yang dilakukan oleh remaja. Pola asuh orang tua akan memengaruhi perilaku remaja, termasuk dalam perilaku seksual. Selain itu, bentuk keluarga memengaruhi perilaku seksual pranikah berisiko tinggi.

Remaja yang berada pada keluarga yang mampu mengontrol pergaulan remajanya dengan baik akan cenderung berperilaku seksual berisiko rendah (Suwarni, 2009). Kedekatan remaja dengan orang tua dibutuhkan untuk dapat membentuk perilaku remaja. Hal ini karena remaja yang membicarakan masalah kesehatan reproduksi dengan keluarga cenderung tidak berperilaku negatif dalam berpacaran (Purwatiningsih dan Furi, 2010).

Keluarga atau orang tua seharusnya dapat berperan dalam memberikan pengetahuan tentang kesehatan reproduksi kepada remaja. Studi Suwarni (2009) menjelaskan bahwa tingkat komunikasi orang tua dengan remaja dalam membicarakan masalah kesehatan reproduksi tergolong rendah. Padahal komunikasi orang tua dengan remaja memiliki peran yang penting. Perilaku seksual pranikah yang dilakukan oleh remaja disebabkan oleh keengganan orang tua untuk terbuka dengan remajanya dalam penyampaian informasi terkait seksualitas (Sarwono, 2010).

Pengetahuan yang dimiliki oleh remaja akan memengaruhi sikap dan perilaku remaja dalam hal seksualitas. Menurut Green (dalam Soekidjo (2007)), perilaku seseorang dipengaruhi oleh faktor-faktor yang mendorong atau memperkuat terjadinya perilaku, seperti sikap dan pengetahuan. Hasil studi terhadap remaja hasil studi Pratiwi dan Hari (2010) juga mendapatkan adanya hubungan yang signifikan antara tingkat pengetahuan tentang kesehatan reproduksi dengan perilaku seksual. 


\section{Metode Penelitian dan Analisis}

Tulisan ini nantinya merupakan hasil dari studi CHAMPSEA wave II tahun 2016 yang merupakan studi longitudinal dari wave I tahun 2008. Studi ini dilakukan pada dua provinsi, yaitu Jawa Barat dan Jawa Timur. Pada setiap provinsi ini, dipilih dua kabupaten yang memiliki tingkat migrasi internasional tertinggi yang kemudian dipilih untuk penyaringan rumah tangga. Rumah tangga yang merupakan responden dari CHAMPSEA wave II ini berjumlah 966 rumah tangga. Sementara itu, artikel ini akan fokus pada data dengan kategori remaja (young adult) dengan sampel sejumlah 429 anak remaja dari rumah tangga migran dan nonmigran.

Prosedur penyaringan responden adalah sebagai berikut. Pertama, karena studi ini merupakan studi panel dari CHAMPSEA wave 1 , maka responden dalam studi ini merupakan responden yang sama dengan responden pada studi wave 1. Pada saat studi wave 1 responden tergolong dalam kriteria anak yang lebih tua (older child) yang berusia 9-11 tahun. Berdasarkan data dari studi wave 1, ditelusuri keberadaan responden tersebut dan diikuti jika responden telah pindah tempat tinggal selama kondisinya masih memungkinkan. Berdasarkan kriteria tersebut, terjaring 429 anak dari rumah tangga migran dan nonmigran yang masih dapat dilacak. Kesulitan yang dihadapi dalam melacak responden adalah beberapa responden telah menikah dan pindah mengikuti suaminya, atau ada juga yang bekerja di luar desa, bahkan di luar kabupaten.

Responden dalam studi ini bergabung secara sukarela. Studi ini mengikuti prosedur bahwa sebelum dilakukan wawancara, responden harus memberikan persetujuan secara tertulis terlebih dulu. Pewawancara akan membacakan informed consent kepada calon responden dan jika bersedia, harus menandatangani informed consent tersebut.

Analisis yang digunakan dalam studi ini adalah deskriptif analitis untuk menggambarkan perilaku seksual remaja pada rumah tangga migran dan nonmigran. Analisis dilakukan terhadap variabel-variabel terpilih yang berkaitan dengan perilaku seksual remaja dan lingkungan yang memengaruhinya. Variabel-variabel yang akan dianalisis adalah sebagai berikut.

1. Perilaku seksual: "Apakah kamu pernah melakukan hubungan seksual?" dan "Pada umur berapa kamu pertama kali melakukan hubungan seksual?";

2. Persepsi remaja: "Menurut kamu, berapa umur ideal untuk perempuan/laki-laki melakukan hubungan seksual?"; "Menurut kamu, berapa umur ideal bagi perempuan/ laki-laki untuk mempunyai anak?"; dan "Menurut kamu, berapa umur ideal bagi perempuan/laki-laki untuk menikah?";

3. Faktor teman: "Apakah ada di antara temanmu yang telah melakukan hubungan seksual?"; "Apakah ada di antara temanmu yang menganjurkanmu melakukan hubungan seksual?"; dan "Apakah ada di antara temanmu yang memaksamu melakukan hubungan seksual?"

Analisis akan membedakan antara remaja pada rumah tangga nonmigran dan rumah tangga migran, dalam tiga jenis rumah tangga (ibu migran, ayah migran, dan kedua orang tua migran). Seperti yang dijelaskan dalam tinjauan teori di atas, lakilaki cenderung lebih permisif dibandingkan dengan perempuan. Oleh karena itu, dalam analisis akan dibedakan perilaku seksual antara remaja laki-laki dan perempuan. Selain itu, keluarga juga berkontribusi terhadap perilaku seksual remajasehingga analisis juga akan dilihat berdasarkan tipe 
rumah tangga dan jenis migrasi orang tua. Lingkungan sosial lain yang berpengaruh terhadap perilaku seksual remaja adalah teman. Remaja lebih memilih teman sebagai tempat untuk membicarakan masalah kesehatan reproduksi. Oleh karena itu, dalam analisis juga akan dilihat perilaku teman responden dalam hal seksualitas.

Di dalam menganalisis perilaku remaja sebagai hasil dari pengaruh lingkungan sosial, tampaknya dapat digunakan teori Giddens tentang strukturasi. Teori ini mencoba mengaitkan relasi antara struktur dan agensi yang dipandang sebagai dualitas atau dua sisi mata uang yang sama (Ashaf, 2006), yaitu struktur dan agensi ini saling memengaruhi dan berlangsung terus-menerus. Struktur dalam hal ini adalah aturan-aturan sosial yang berlaku di masyarakat, sedangkan agensi adalah individu atau remaja. Giddens menganggap bahwa struktur bukan hanya media, tetapi juga hasil dari tingkah laku yang dilakukan secara berulang. Dengan kata lain, struktur bukan hanya memandu perilaku, tetapi juga merupakan akibat dari perilaku agen dalam proses produksi dan reproduksi sistem sosial.

\section{Hasil dan Pembahasan}

\section{Karakteristik Responden}

Responden dalam studi ini memiliki tingkat pendidikan yang tergolong cukup tinggi karena lebih dari 50 persen berpendidikan SMA. Namun, jika dilihat berdasarkan jenis kelamin, responden yang berpendidikan SMA lebih banyak perempuan, yaitu 56,50 persen, sedangkan responden laki-laki 43,20 persen. Pada responden laki-laki lebih banyak yang berpendidikan SMP, yaitu 49,51 persen, sedangkan responden perempuan yang berpendidikan SMP 38,57 persen.
Berdasarkan data pendidikan anak tersebut, partisipasi sekolah anak perempuan lebih tinggi daripada laki-laki juga sesuai dengan data BPS. Data tersebut ditunjukkan pada data tentang Angka Partisipasi Kasar (APK) tingkat SMA/SMK sederajat tahun 2015 dan 2016 bahwa APK pada kelompok perempuan lebih tinggi dibandingkan dengan laki-laki. APK untuk jenjang SMA pada 2015 adalah76,40 untuk kelompok laki-laki dan 79,77 pada kelompok jenis kelamin perempuan. Sementara itu, pada 2016 APK mengalami peningkatan, yaitu 80,51 untuk jenis kelamin laki-laki dan 81,29 untuk jenis kelamin perempuan (BPS, 2016).

Selanjutnya dilihat dari status pernikahan, 3,5 persen responden dalam kategori remaja telah menikah. Remaja dengan status telah menikah lebih banyak ditemukan di daerah perdesaan. Data BPS juga menunjukkan bahwa perkawinan anak di daerah perdesaan lebih tinggi dibandingkan dengan daerah perkotaan, yaitu masing-masing 29,2 persen dan 19,0 persen pada 2012 (BPS, 2016). Jika dilihat berdasarkan jenis kelamin, maka responden perempuan lebih banyak yang telah menikah, yaitu 5,38 persen, sedangkan lakilaki hanya 1,46 persen. Hal ini kemungkinan sesuai dengan tradisi di masyarakat bahwa perempuan biasanya lebih dulu menikah dibandingkan dengan laki-laki.

Anak perempuan akan lebih dulu dinikahkan sebagai akibat dari adanya ketidaksetaraan gender di masyarakat. Mereka beranggapan bahwa peran perempuan adalah sebagai istri dan ibu sehingga mereka lebih besar kemungkinannya untuk dinikahkan pada usia muda. Selain itu, biasanya alasan pernikahan anak perempuan yang lebih cepat dibandingkan dengan laki-laki adalah alasan ekonomi (BPS, 2016). Di samping itu, data SDKI 2012 menunjukkan bahwa 17 persen perempuan pernah kawin yang berusia 20-24 
Tabel 1 Karakteristik Demografi Responden

\begin{tabular}{lrrrrrr}
\hline \multirow{2}{*}{ Karakteristik Responden } & \multicolumn{2}{c}{ Laki-laki } & \multicolumn{2}{c}{ Perempuan } & \multicolumn{2}{c}{ Total } \\
\cline { 2 - 8 } & $\mathbf{n}$ & \multicolumn{1}{c}{$\%$} & $\mathbf{n}$ & \multicolumn{1}{c}{$\%$} & $\mathbf{n}$ & $\%$ \\
\hline Tingkat Pendidikan: & & & & & & \\
- Tidak bersekolah & 2 & 0,97 & 0 & 0,00 & 2 & 0,47 \\
- TK & 2 & 0,97 & 0 & 0,00 & 2 & 0,47 \\
- SD & 11 & 5,34 & 11 & 4,93 & 22 & 5,13 \\
- SMP & 102 & 49,51 & 86 & 38,57 & 188 & 43,82 \\
- SMA & 89 & 43,20 & 126 & 56,50 & 215 & 50,12 \\
\hline Status Pernikahan: & & & & & & \\
- Menikah & 3 & 1,46 & 12 & 5,38 & 15 & 3,50 \\
- Belum Menikah & 203 & 98,54 & 211 & 94,62 & 414 & 96,50 \\
\hline Status Migran Orang tua: & & & & & & \\
- Ayah Migran & 23 & 11,17 & 25 & 11,21 & 48 & 11,19 \\
- Ibu Migran & 28 & 13,59 & 25 & 11,21 & 53 & 12,35 \\
- Ayah dan Ibu Migran & 6 & 2,91 & 7 & 3,14 & 13 & 3,03 \\
- Bukan Migran & 149 & 72,33 & 166 & 74,44 & 315 & 73,43 \\
Jumlahy & & & & & & \\
\hline
\end{tabular}

Sumber: Data CHAMPSEA, 2016

tahun melaporkan bahwa mereka menikah sebelum usia 18 tahun. Lebih banyaknya perempuan yang menikah pada usia muda ini juga didukung oleh masih kuatnya budaya patriarki di masyarakat yang lebih banyak mengontruksi perempuan dalam ranah domestik dan fungsi reproduksi (Puspitawati, 2012).

Pada studi CHAMPSEA wave 2 ini jumlah responden yang tergolong kategori rumah tangga nonmigran mengalami peningkatan dibandingkan dengan data pada wave 1 . Jumlah responden kategori rumah tangga nonmigran pada data wave 2 berjumlah 315 , sedangkan pada wave 1 berjumlah 247 responden dan jumlah responden kategori rumah tangga migran adalah 266. Oleh karena itu, kemungkinan telah terjadi perubahan, yang dulunya merupakan migran telah berubah menjadi nonmigran karena responden pada wave 2 merupakan responden yang sama dengan wave 1. Dengan demikian, terjadi perubahan yang cukup besar karena lebih dari 20 persen rumah tangga yang dulunya adalah migran telah berubah menjadi nonmigran.

\section{Perilaku Seksual Remaja}

Data CHAMPSEA 2016 menunjukkan bahwaterdapat 5,07 persen remaja yang belum menikah telah melakukan hubungan seksual pranikah. Jika dilihat dari persentasenya, tampak bahwa angkanya relatif kecil. Namun, menanyakan tentang perilaku seksual pada remaja bukan persoalan yang mudah karena belum tentu remaja akan mengakui tentang perilaku seksnya. Oleh karena itu, ada kemungkinan prevalensi remaja yang telah melakukan hubungan seksual pranikah angkanya lebih besar dari data tersebut. 
Tabel 2 Remaja yang Telah Melakukan Hubungan Seksual Pranikah

\begin{tabular}{lrrrrrr}
\hline & \multicolumn{1}{c}{ Laki-laki } & \multicolumn{2}{c}{ Perempuan } & \multicolumn{2}{c}{ Total } \\
\cline { 2 - 7 } & $\mathbf{n}$ & \multicolumn{1}{c}{$\%$} & $\mathbf{n}$ & \multicolumn{1}{c}{$\%$} & $\mathbf{n}$ & \multicolumn{1}{c}{$\%$} \\
\cline { 2 - 7 } & 9 & 4,43 & 12 & 5,69 & 21 & 5,07 \\
Ya & 193 & 95,07 & 199 & 94,31 & 392 & 94,69 \\
Menolak Menjawab & 1 & 0,49 & 0 & 0,00 & 1 & 0,24 \\
Total & 203 & 100,00 & 211 & 100,00 & 413 & 100,00 \\
\hline
\end{tabular}

Sumber: Data CHAMPSEA, 2016

Perilaku seksual pranikah lebih menunjukkan remaja perempuan lebih banyak dilakukan oleh remaja perempuan permisif juga berbeda dengan temuan dibandingkan dengan remaja laki- Putri (2014) dan Mahmudah, dkk. (2016) laki. Berdasarkan data berikut, remaja yang menunjukkan bahwa remaja laki-laki perempuan yang telah melakukan hubungan cenderung lebih permisif dibandingkan seksual pranikah sebanyak 5,69 persen, dengan remaja perempuan.

sedangkan remaja laki-laki sebanyak 4,43 persen. Temuan ini sedikit berbeda dengan data Survei Kesehatan Reproduksi Remaja Indonesia (SKRRI) 2012 yang menunjukkan bahwa remaja laki-laki cenderung lebih permisif dibandingkan dengan remaja perempuan. Data hasil CHAMPSEA yang

Hasil studi CHAMPSEA ini sejalan dengan studi Suparmi (2015) yang juga menunjukkan bahwa remaja perempuan lebih banyak yang melakukan perilaku seksual pranikah dibandingkan dengan remaja laki-laki. Selain itu, hasil penelitian Nurhayati (2011) juga menunjukkan bahwa remaja perempuan

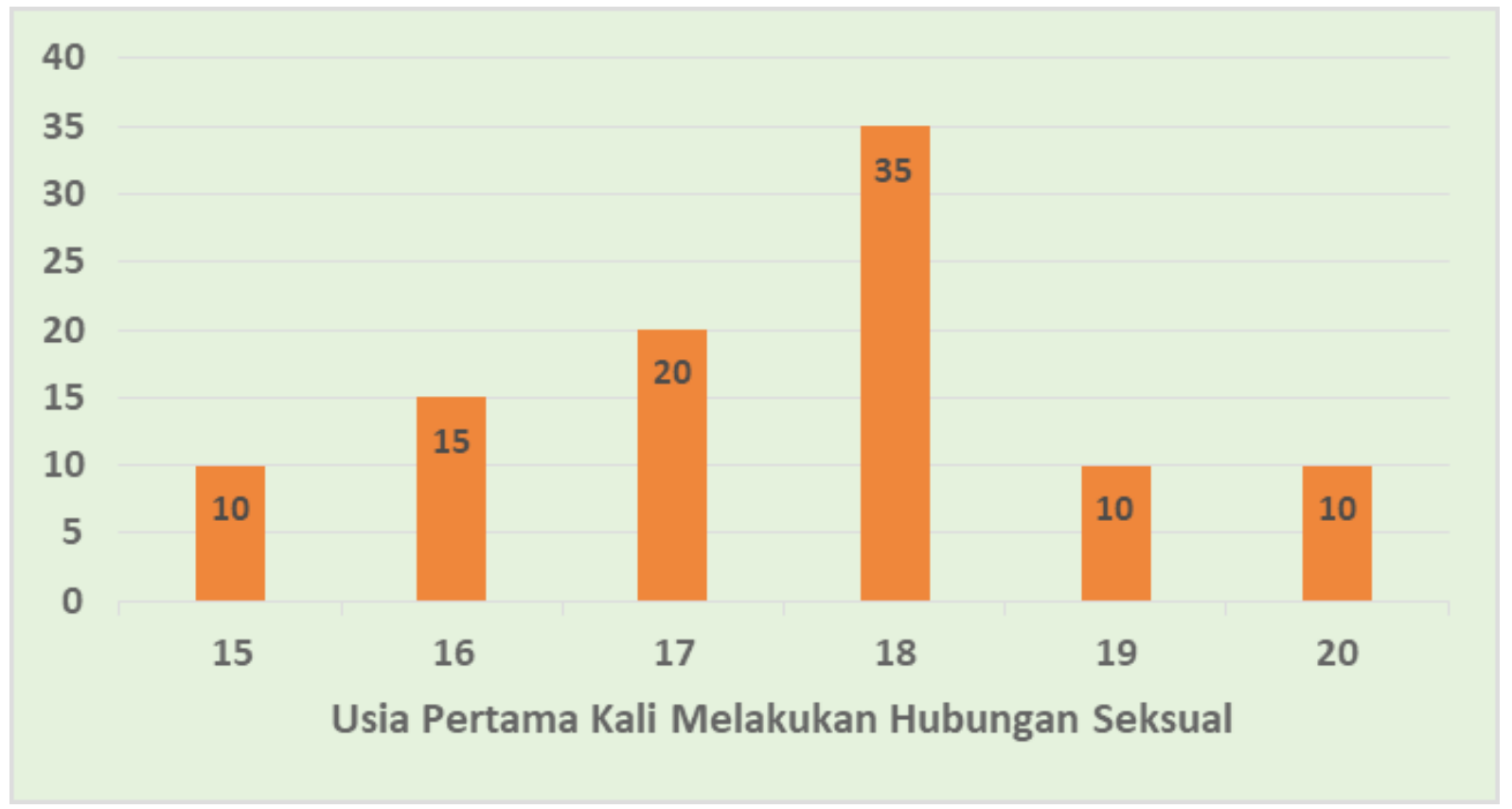

Sumber: Data CHAMPSEA, 2016

Grafik 1 Usia Pertama Kali Melakukan Hubungan Seksual 
memiliki perilaku seksual berisiko lebih tinggi daripada remaja laki-laki. Berdasarkan beberapa temuan tersebut, tampak bahwa jenis kelamin tidak dapat menjadi faktor yang mutlak dalam perilaku seksual berisiko pada remaja. Hal ini berarti baik remaja laki-laki maupun perempuan, keduanya memiliki risiko untuk berperilaku seksual yang berisiko.

Namun, sering kali di masyarakat ada perbedaan pandangan terhadap perilaku remaja laki-laki dan perempuan. Pada remaja laki-laki ada kecenderungan untuk membiarkan atau membolehkan perilakuperilaku yang dipandang negatif, sedangkan pada perempuan akan dilakukan pembatasanpembatasan. Hal ini dipengaruhi oleh budaya patriarki yang menafsirkan perbedaan biologis menjadi indikator kepantasan dalam berperilaku yang akhirnya berujung pada pembatasan hak, akses, partisipasi, kontrol, serta menikmati manfaat dari sumber daya dan informasi. Akhirnya tuntutan peran, tugas, kedudukan, dan kewajiban yang pantas dilakukan oleh laki-laki atau perempuan dan yang tidak pantas dilakukan oleh laki-laki atau perempuan sangat bervariasi di masyarakat (Puspitawati, 2012).

Perbedaan pandangan pada laki-laki dan perempuan juga dipengaruhi oleh konstruksi sosial yang menyebabkan peran-peran sosial yang bias gender (Setiadi, 2011). Perempuan memiliki peran domestik, sedangkan lakilaki pada peran publik,sehingga perempuan memiliki keterbatasan terhadap akses dan kontrol sosial. Hal itulah yang menyebabkan masyarakat lebih permisif terhadap perilaku seksual laki-laki, sedangkan pada perempuan yang memiliki perilaku seksual berisiko akan mendapatkan sanksi sosial lebih berat daripada laki-laki.
Sementara itu, usia pertama kali melakukan hubungan seksual pranikah paling banyak dilakukan oleh remaja yang berusia 18 tahun (35 persen). Kemudian yang terbanyak kedua dilakukan oleh remaja yang telah berusia 17 tahun (20 persen) dan selanjutnya remaja yang berusia 16 tahun (15 persen). Usia pertama kali melakukan hubungan seksual ini jika dibandingkan dengan studi lainnya terdapat perbedaan. Hasil studi Suryoputro, dkk. (2006) menunjukkan bahwa usia pertama kali berhubungan seks dilakukan pada usia di atas 18 tahun, yaitu 55 persen, sedangkan yang melakukan hubungan seks pada usia 16-18 tahun sebanyak 40 persen. Kemudian studi Putri (2014) menjelaskan bahwa perilaku seksual pranikah berisiko tinggi terbanyak dilakukan oleh remaja usia 19 tahun (37,5 persen), kemudian remaja usia 18 tahun (13,0 persen), sedangkan pada usia di bawahnya, persentasenya di bawah 10 persen. Data SDKI (2012) juga menunjukkan bahwa 17 persen dari perempuan pernah kawin usia 20-24 tahun menikah sebelum usia 18 tahun.

Hasil studi CHAMPSEA justru menunjukkan bahwa remaja yang melakukan hubungan seksual pranikah di atas 18 tahun jauh lebih sedikit. Studi CHAMPSEA justru menunjukkan bahwa perilaku seksual pranikah paling banyak dilakukan oleh remaja usia 16-18 tahun dan terbanyak dilakukan oleh remaja usia 18 tahun. Hal ini karena terjadi perbedaan wilayah, karena studi Suryoputro (2006) dan Putri (2014) dilakukan di perkotaan, sedangkan studi CHAMPSEA dilakukan di wilayah perdesaan. Di samping itu, ada kemungkinan remaja usia di atas 18 tahun di perdesaan telah dinikahkan sehingga tidak tergolong dalam perilaku seksual berisiko. 
Tabel 3 Umur Ideal Untuk Perempuan/Laki-Laki Melakukan Hubungan Seksual

\begin{tabular}{lrr}
\hline \multicolumn{1}{c}{ Usia } & Jumlah & Persen \\
\hline 20 tahun kebawah & 52 & 12,12 \\
$21-25$ & 289 & 67,37 \\
$>25$ & 83 & 19,35 \\
Menolak Menjawab & 1 & 0,23 \\
Tidak tahu & 4 & 0,93 \\
Total & 429 & 100,00 \\
\hline
\end{tabular}

Sumber: Data CHAMPSEA, 2016

Perilaku remaja berdasarkan data yang tergolong telah dewasa meskipun CHAMPSEA ini berbeda dengan persepsi perilaku seksual telah mereka praktikkan mereka tentang usia ideal bagi laki-laki maupun perempuan untuk melakukan hubungan seksual. Jika pada usia di bawah 18 tahun di kalangan mereka telah banyak yang melakukan hubungan seksual, menurut persepsi mereka, usia yang ideal untuk melakukan hubungan seksual adalah pada usia 21-25 tahun (67,37 persen). Hal itu berarti bahwa sebagian besar dari responden berpersepsi bahwa hubungan seksual paling ideal dilakukan pada usia pada usia remaja.

Persepsi tentang usia ideal untuk melakukan hubungan seksual di atas juga sejalan dengan persepsi remaja tentang usia ideal untuk menikah dan mempunyai anak. Sebagian besar responden berpendapat bahwa usia ideal untuk menikah adalah pada usia 21-25 tahun (75,52 persen), sedangkan yang berpendapat pada usia di bawah 20 tahun hanya 8,16 persen dan di atas 25 tahun 15,85 persen.

Tabel 4 Umur Ideal untuk Menikah dan Mempunyai Anak

\begin{tabular}{lrrrr}
\hline \multirow{2}{*}{ Usia } & \multicolumn{2}{c}{ Menikah } & \multicolumn{2}{c}{ Mempunyai Anak } \\
\cline { 2 - 5 } & Jumlah & Persen & Jumlah & Persen \\
\hline 20 tahun ke bawah & 35 & 8,16 & 17 & 3,96 \\
& & & & \\
$21-25$ & 324 & 75,52 & 199 & 46,39 \\
& & & & \\
$>25$ & & & & \\
Tidak tahu & 68 & 15,85 & 211 & 49,18 \\
Total & 2 & 0,47 & 2 & 0,47 \\
\hline
\end{tabular}

Sumber: Data CHAMPSEA, 2016 
Hasil CHAMPSEA ini sesuai dengan data SDKI 2012 yang menunjukkan bahwa persepsi remaja mengenai usia ideal untuk menikah bagi perempuan yang terbanyak menjawab pada usia 20-24 tahun (59,2 persen) pada responden perempuan kelompok usia 15-19 tahun. Sementara itu, pada responden remaja laki-laki, angkanya lebih tinggi, yaitu 62,6 persen. Kemudian menurut persepsi laki-laki, usia ideal bagi laki-laki untuk menikah adalah pada usia di atas 25 tahun, yaitu sebanyak 75,5 persen.

Sementara itu, jika dilihat dari wilayah tempat tinggal, data SDKI tidak menunjukkan adanya perbedaan antara perkotaan dan perdesaan. Remaja perempuan yang tinggal di wilayah perkotaan mengatakan bahwa usia ideal untuk menikah bagi perempuan adalah usia 20-24 tahun (57,2 persen), sedangkan yang tinggal di perdesaan sebanyak 57,5 persen. Kemudin usia ideal bagi laki-laki untuk menikah adalah di atas 25 tahun yang dijawab oleh 84,9 persen responden di perkotaan dan 75,5 persen di perdesaan.

Pada kelompok remaja laki-laki juga tidak ada perbedaan antara remaja di perkotaan dan perdesaan. Sebanyak 65,5 persen remaja laki-laki di perkotaan mengatakan bahwa usia ideal untuk menikah bagi perempuan adalah usia 20-24 tahun dan 62,0\% remaja laki-laki di perdesaan mengatakan hal yang sama. Sementara itu, usia ideal bagi laki-laki untuk menikah adalah di atas 25 tahun yang dijawab oleh 78,9 persen responden di perkotaan dan 72,9 persen di perdesaan.

\section{Ayah \& Ibu Non Migran}

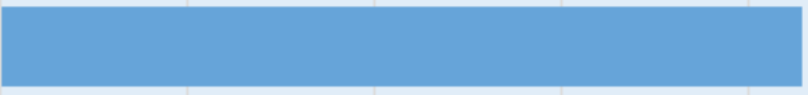

Ayah \& Ibu Migran

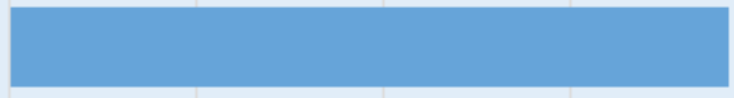

7,69

Ibu Migran

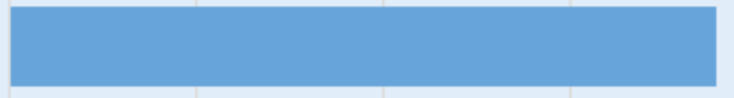

7,55

Ayah Migran

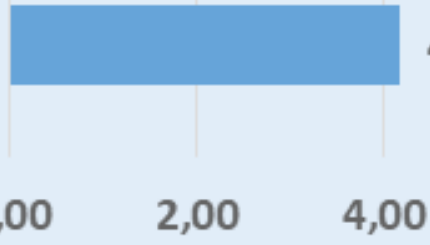

4,17

\section{0,00}

2,00

6,00

8,00

10,00

Sumber: Data CHAMPSEA, 2016

Grafik 2 Remaja Pernah Melakukan Hubungan Seksual berdasarkan Status Migran Orang Tua 
Data CHAMPSEA (2016) menunjukkan bahwa hubungan seksual pranikah pada remaja dilakukan oleh remaja dengan orang tua sebagai migran maupun pada nonmigran. Data tersebut mengindikasikan bahwa absennya orang tua tidak selalu berkorelasi dengan perilaku seksual remaja meskipun kontrol orang tua memiliki pengaruh yang signifkan terhadap aktivitas sosial remaja. Namun, perilaku seksual remaja lebih disebabkan oleh rendahnya pengawasan orang tua atau monitoring parental. Dalam hal ini, bagi remaja yang ditinggal orang tua bermigrasi, fungsi parenting digantikan oleh famili dan biasanya oleh nenek dan ternyata hal itu masih cukup efektif menggantikan peran orang tua dalam fungsi parenting.

Grafik 2 di atas menunjukkan bahwa perilaku seksual paling sedikit dilakukan oleh remaja dengan status ayah migran. Peran ibu menjadi penting dalam pembentukan perilaku remaja sehingga saat anak remaja masih dalam pengawasan ibu tampaknya lebih memiliki perilaku yang positif. Hal ini seperti yang dijelaskan oleh Suwarni (2009) yang menunjukkan ada hubungan antara monitoring parental dengan perilaku seksual remaja, yaitu remaja dengan monitoring parental rendah akan memiliki perilaku seksual berisiko dibandingkan dengan remaja dengan monitoring parental yang tinggi.

Data hasil CHAMPSEA ini menjadi berbeda dengan pernyataan Monks, dkk. (2002) bahwa remaja yang tinggal bersama orang tua dan memperlihatkan komunikasi yang baik akan membuat perilaku seksual yang rendah pada remaja tersebut. Namun, data CHAMPSEA tersebut justru menunjukkan bahwa remaja dari keluarga nonmigran juga memiliki perilaku seksual berisiko. Hal ini sejalan dengan studi dari Maryatun dan Purwaningsih (2012) yang menunjukkan bahwa tidak ada hubungan yang signifikan antara peran orang tua dengan perilaku seksual remaja.

\section{Lingkungan Sosial Remaja}

Lingkungan sosial merupakan salah satu faktor yang dapat memengaruhi tindakan dan perubahan-perubahan perilaku setiap individu. Lingkungan sosial ini dapat berbentuk perorangan maupun dalam bentuk kelompok keluarga, teman sepermainan, tetangga, warga desa, warga kota, bangsa, dan seterusnya (Yudistira, 1997). Namun, teman merupakan lingkungan yang paling berpengaruh terhadap perilaku remaja. Jika melihat teori Giddens yang menjelaskan bahwa remaja sebagai agen dan lingkungan sosial sebagai struktur, keduanya akan saling memengaruhi sehingga aturan-aturan yang terdapat di lingkungan sosial dapat berubah seiring dengan perkembangan perilaku remaja.

Hal ini seperti yang muncul dari olah data CHAMPSEA yang menunjukkan bahwa anak-anak yang menjadi responden dalam penelitian ini mengatakan bahwa mereka memiliki teman yang telah melakukan hubungan seksual. Sebanyak 28,74 persen atau 124 dari responden memiliki teman yang telah melakukan hubungan seksual pranikah. Selain itu, di antara teman remaja ada yang menganjurkan melakukan hubungan seksual sebesar 9,09 persen. Ada di antara teman yang, bahkan memaksa melakukan hubungan seksual dengan persentase sebanyak 3,05 persen. Hal itu berarti remaja tinggal di dalam lingkungan yang telah melakukan praktik seksual berisiko. Studi sebelumnya menunjukkan bahwa teman sebaya memiliki peran terhadap perilaku seks pranikah (Suparmi dan Isfandari, 2016).

Faktor teman atau lingkungan pergaulan dan remaja akan saling berkaitan karena keduanya akan saling memengaruhi yang disebabkan oleh perilaku sosial merupakan hal yang bersifat mengalir, seperti yang 
dijelaskan dalam teori Giddens (dalam Ashaf, 2006). Remaja sebagai agen dalam melakukan tindakan sosial akan saling memengaruhi dengan lingkungan sosialnya. Dengan demikian, remaja yang melakukan praktik seksual berisiko akan memengaruhi lingkungannya, demikian juga jika remaja bergaul dengan lingkungan sosial yang melakukan praktik seksual berisiko juga akan memengaruhi perilaku remaja.

Kemudian jika dilihat dari status pernikahannya, pada umumnya mereka berstatus belum menikah. Terkait dengan perilaku teman, baik perilaku telah melakukan hubungan seksual, menganjurkan ataupun memaksa melakukan hubungan seksual, lebih dari 90 persen dilakukan oleh teman yang berstatus belum menikah. Padahal Brown (dalam Santrock, 2007) menjelaskan tentang peran teman terhadap pembentukan perilaku dan membangun identitas remaja. Oleh karena itu, lingkungan sosial, dalam hal ini teman memiliki peran penting terhadap remaja.

Sementara itu, dilihat berdasarkan perbedaan jenis kelamin, remaja laki-laki cenderung lebih permisif dibandingkan dengan remaja perempuan. Hal ini dilihat dari perilaku seksual remaja yang dilakukan oleh temannya, yaitu telah melakukan hubungan

\section{Tabel 5 Distribusi Perilaku Seksual Remaja Berdasarkan Karakteristik Demografi}

\begin{tabular}{|c|c|c|c|c|c|c|}
\hline \multirow[t]{2}{*}{ Karakteristik Teman } & \multicolumn{2}{|c|}{$\begin{array}{c}\text { Telah melakukan } \\
\text { hubungan } \\
\text { seksual }\end{array}$} & \multicolumn{2}{|c|}{$\begin{array}{c}\text { Menganjurkan } \\
\text { melakukan } \\
\text { hubungan } \\
\text { seksual }\end{array}$} & \multicolumn{2}{|c|}{$\begin{array}{c}\text { Memaksa } \\
\text { melakukan } \\
\text { hubungan } \\
\text { seksual }\end{array}$} \\
\hline & $\mathrm{n}$ & $\%$ & $\mathrm{n}$ & $\%$ & $\mathrm{n}$ & $\%$ \\
\hline $\begin{array}{l}\text { Jenis Kelamin: } \\
\text { - Laki-laki } \\
\text { - Perempuan }\end{array}$ & $\begin{array}{l}66 \\
58\end{array}$ & $\begin{array}{l}53,23 \\
46,77\end{array}$ & $\begin{array}{l}23 \\
16\end{array}$ & $\begin{array}{l}58,97 \\
41,03\end{array}$ & $\begin{array}{r}11 \\
4\end{array}$ & $\begin{array}{l}73,33 \\
26,67\end{array}$ \\
\hline $\begin{array}{l}\text { Jenis Rumah Tangga: } \\
\text { - Nonmigran } \\
\text { - Ayah Migran } \\
\text { - Ibu Migran } \\
\text { - Kedua Orang tua } \\
\text { migran }\end{array}$ & $\begin{array}{r}89 \\
13 \\
15 \\
7\end{array}$ & $\begin{array}{r}79,41 \\
5,88 \\
11,76 \\
2,94\end{array}$ & $\begin{array}{r}27 \\
3 \\
7 \\
2\end{array}$ & $\begin{array}{r}69,23 \\
7,69 \\
17,95 \\
5,13\end{array}$ & $\begin{array}{l}9 \\
2 \\
4 \\
0\end{array}$ & $\begin{array}{r}60,00 \\
13,33 \\
26,77 \\
0\end{array}$ \\
\hline $\begin{array}{l}\text { Status Pernikahan: } \\
\text { - Menikah } \\
\text { - Belum Menikah }\end{array}$ & $\begin{array}{r}5 \\
119\end{array}$ & $\begin{array}{r}4,03 \\
95,97\end{array}$ & $\begin{array}{r}2 \\
37\end{array}$ & $\begin{array}{r}5,13 \\
94,87\end{array}$ & $\begin{array}{r}1 \\
14\end{array}$ & $\begin{array}{r}6,67 \\
93,33\end{array}$ \\
\hline $\begin{array}{l}\text { Tingkat Pendidikan: } \\
\text { - Tidak Sekolah } \\
\text { - SD } \\
\text { - SMP } \\
\text { - SMA }\end{array}$ & $\begin{array}{r}0 \\
5 \\
55 \\
64\end{array}$ & $\begin{array}{r}0,00 \\
4,03 \\
44,35 \\
51,61\end{array}$ & $\begin{array}{r}0 \\
3 \\
26 \\
10\end{array}$ & $\begin{array}{r}0,00 \\
7,69 \\
66,67 \\
25,64\end{array}$ & $\begin{array}{l}0 \\
1 \\
9 \\
5\end{array}$ & $\begin{array}{r}0,00 \\
6,67 \\
60,00 \\
33,33\end{array}$ \\
\hline Jumlah & 124 & 100,0 & 39 & 100,0 & 15 & 100,0 \\
\hline
\end{tabular}

Sumber: Data CHAMPSEA, 2016 
seksual, menganjurkan melakukan hubungan seksual, dan memaksa melakukan hubungan seksual, lebih banyak dilakukan oleh remaja laki-laki. Pada remaja yang memiliki teman yang memaksa melakukan hubungan seksual dilakukan oleh 73,33 persen teman laki-laki dan yang menganjurkan melakukan hubungan seksual dilakukan oleh 58,97 persen teman laki-laki.

Penelitian sebelumnya juga menunjukkan bahwa remaja laki-laki cenderung lebih permisif dibandingkan dengan perempuan (Purwatiningsih dan Furi, 2010 dan Setyo dan Notobroto, 2013). Selain itu, penelitian Putri (2014) juga menunjukkan bahwa perilaku seksual pranikah berisiko tinggi terbanyak dilakukan oleh remaja laki-laki. Sementara itu, remaja laki-laki yang memiliki teman pernah melakukan hubungan seksual pranikah memiliki risiko 10,63 kali lebih besar untuk melakukan perilaku seksual pranikah (Suparmi dan Isfandari, 2016). Faktor yang menyebabkan anak laki-laki lebih permisif adalah karena penerapan norma yang berbeda. Sarwono (2012) juga menjelaskan bahwa norma yang diterapkan pada laki-laki cenderung lebih longgar dibandingkan dengan perempuan, selain juga orang tua cenderung lebih protektif terhadap anak perempuan.

Sementara itu, jika dilihat dari status migrasi orang tua, tampaknya status migrasi orang tua tidak selalu berkaitan dengan perilaku seksual remaja. Berdasarkan Tabel 5, perilaku seksual pranikah dilakukan oleh teman remaja pada berbagai jenis rumah tangga, yaitu baik pada rumah tangga migran maupun rumah tangga nonmigran. Teman lebih memiliki peran dalam pembentukan perilaku remaja karena mereka lebih banyak meluangkan waktu bersama temannya.

Remaja mulai memperluas pergaulan sosialnya dengan teman-teman sebayanya. Selain itu, remaja lebih sering berada di luar rumah bersama teman teman sebayanya. Oleh karena itu, dapat dimengerti jika pengaruh teman-teman sebayanya pada sikap, minat, penampilan, dan perilaku lebih besar daripada pengaruh orang tua. Widyastuti (2009) juga menyatakan bahwa teman adalah sumber penting dalam sosialisasi seksual bagi remaja, sebab teman selalu ada saat remaja ingin mengeksplorasi diri.

Pengaruh teman ini dapat dilihat dari perilaku seksual remaja. Data CHAMPSEA menunjukkan bahwa remaja yang telah pernah melakukan hubungan seksual dan memiliki teman yang juga telah melakukan hubungan seksual sebanyak 16,94 persen. Hal ini sejalan dengan studi Suparmi dan Isfandari (2016) yang menyatakan bahwa teman sebaya memiliki kontribusi terhadap perilaku seksual remaja. Selain itu, studi sebelumnya juga menunjukkan bahwa ada hubungan antara perilaku seksual teman sebaya dengan perilaku seksual remaja (Suwarni, 2009). Studi tersebut menunjukkan bahwa bahwa teman tidak hanya berpengaruh pada sikap remaja terhadap seksualitas, tetapi juga pada proses pengambilan keputusan lainnya, seperti pertimbangan keluar sekolah, membolos, termasuk keputusan untuk melakukan hubungan seks pertama kali.

Interaksi remaja terhadap lingkungan sosial akan membentuk perilakunya yang pada gilirannya akan berpengaruh terhadap praktik sosial remaja di masyarakat. Di dalam melakukan tindakan sosial, remaja sebagai agen akan melakukan apa yang disebutkan Giddens sebagai pemantauan reflektif, yaitu sebuah proses terus-menerus ketika remaja tidak hanya dipengaruhi oleh struktur, tetapi juga memengaruhi struktur. Hal ini dapat dilihat dari adanya perubahan di masyarakat yang cenderung menjadi lebih permisif terhadap perilaku-perilaku remaja. 


\section{Kesimpulan}

Hasil CHAMPSEA 2016 menunjukkan bahwa remaja yang tinggal di perdesaan juga telah melakukan perilaku seksual berisiko atau perilaku seksual pranikah. Data CHAMPSEA 2016 tersebut menunjukkan bahwa terdapat 5,07 persen remaja yang belum menikah telah melakukan hubungan seksual pranikah. Perilaku ini dilakukan, baik oleh remaja dari keluarga migran maupun dari keluarga nonmigran. Data tersebut mengindikasikan bahwa absennya orang tua tidak selalu berkorelasi dengan perilaku seksual remaja.

Sementara itu, jika dilihat berdasarkan jenis kelamin, perilaku seksual pranikah lebih banyak dilakukan oleh remaja perempuan dibandingkan dengan remaja laki-laki. Hasil studi ini juga didukung oleh beberapa studi sebelumnya meskipun lebih banyak studi yang menunjukkan bahwa remaja laki-laki cenderung lebih permisif dibandingkan dengan perempuan. Kemudian jika dilihat dari usia pertama kali melakukan hubungan seksual, maka usia pertama kali melakukan hubungan seksual pranikah paling banyak dilakukan oleh remaja yang berusia 18 tahun (35 persen). Namun, usia pertama kali melakukan hubungan seksual ini berbeda dengan persepsi mereka tentang usia ideal untuk melakukan hubungan seksual. Berdasarkan persepsi mereka, sebanyak 67,37 persen mengatakan bahwa usia yang ideal untuk melakukan hubungan seksual adalah pada usia 21-25 tahun.

Sementara itu, berdasarkan lingkungan sosial remaja, terdapat 28,74 persen responden yang memiliki teman telah melakukan hubungan seksual pranikah. Padahal teman berperan terhadap pembentukan perilaku dan membangun identitas remaja. Dengan demikian, perilaku seksual remaja tersebut lebih banyak dipengaruhi oleh perilaku teman sebayanya. Oleh karena itu, diperlukan pengawasan dari orang tua terhadap pergaulan dan perilaku remaja. Meskipun remaja bukan berasal dari keluarga migran, jika tidak ada pengawasan dari orang tua, maka lingkungan sosial akan lebih memengaruhi pembentukan perilaku remaja.

\section{Daftar Pustaka}

Ashaf, Abdul Firman. 2006. "Pola Relasi Media, Negara, dan Masyarakat: Teori Strukturasi Anthony Giddens sebagai Alternatif" dalam Sosiohumaniora, Vol. 8, No. 2, Juli 2006: 205-218.

BPS. 2016. "Statistik Penddidikan 2016". (https://www.bps.go.id/ dynamictable/2018/06/05/1432/ angka-partisipasi-kasar-apk-smasmk-ma-sederajat-menurut-jeniskelamin-2015---2016.html). Diunduh pada 20 Juli 2018. Jakarta. BPS, BKKBN, dan Kemenkes. R.I. 2013. Laporan Pendahuluan Survei Kesehatan Reproduksi Remaja Indonesia Tahun 2012. Jakarta.

BPS dan UNICEF. 2016. Analisis Data Perkawinan Usia Anak di Indonesia. Jakarta: BPS.

Darmayanti, Y., Yuniar Lestari, dan Mery Ramadani. 2011. "Peran teman sebata terhadap perilaku seksual pranikah siswa SLTA Kota Bukittinggi" dalam Jurnal Kesehatan Masyarakat, September 2011-Maret 2011, Vol. 6, No. I: 24-27.

Effendi dan Makhfudli. 2009. Keperawatan Kesehatan Komunitas: Teori dan Praktik dalam Keperawatan. Jakarta: Salemba Medika.

Giddens, A. 2003. The Constitution of Society: Teori Strukturasi untuk Analisis Sosial (D. A. L. Sujono, Trans.). Pasuruan: Penerbit Pedati. House, James S., Landis, Karl L., Umberson, Debra. 2003. "Social relationship and health" dalam Science. 2003: 24; 540-545. 
Mahmudah, Yaslinda Yaunin, dan Yuniar Lestari. 2016. "Faktor-Faktor yang Berhubungan dengan Perilaku Seksual Remaja di Kota Padang" dalam Jurnal Kesehatan Andalas, 5(2): 448-455.

Maryatun \& Purwaningsih, W. 2012. "Hubungan Pengetahuan dan Peran Keluarga dengan Perilaku Seksual Pra Nikah pada Remaja Anak Jalanan Di Kota Surakarta". Ganter, 9 (2): 22-29.

Nasution, Sri Lilestina. 2012. "Pengaruh Pengetahuan tentang Kesehatan Reproduksi Remaja terhadap Perilaku Seksual Pranikah Remaja di Indonesia" dalam Widyariset Vol. 15 No.1, April 2012: 75-84.

Notoatmodjo, Soekidjo. 2007. Promosi Kesehatan dan IImu Perilaku. Jakarta: Rineka Cipta.

Pearson J., Muller C., dan Frisco M. 2006. "Parental Involvement, Family Structure, and Adolescent Sexual Decision Making" dalam Sociological Perspectives. 49(1): 67-90.

Pratiwi NL dan Hari, B. 2010. "Analisis hubungan perilaku seks pertama kali tidak aman pada remaja usia 15-24 tahun dan kesehatan reproduksi" dalam Buletin Penelitian Sistem Kesehatan. 2010: 13(4)

Purbono, Amir Arief., Melly Prabawati., dan Tarma. 2015. "Tingkat Pengetahuan Remaja tentang Kesehatan Reproduksi" dalam Jurnal FamilyEdu. Vol. 1 No. 2 Oktober 2015: 135-149.

Puspitawati, Herien. 2012. Gender dan Keluarga: Konsep dan Realitadi Indonesia. Bogor: PT IPB Press.

Putri, Berliana Devianti. 2014. "Peran Faktor Keluarga Dan Karakteristik Remaja Terhadap Perilaku Seksual Pranikah" dalam Jurnal Biometrika dan Kependudukan, Vol. 3, No. 1 Juli 2014: 8-19.

Rahman AA, Ismail SB, Ibrahim MI, Ali SH, Salleh H, Wan Muda WA. 2015. Factors associated with attitude toward premarital sexual activities among school-going adolescents in Kelantan, Malaysia. Asia - Pacific Journal of Public Health/Asia Pacific Academic Consortium for Public Health, 27(2), 49 - 56.

Santrock. 2007. Remaja. Edisi 11 Jilid 2. Jakarta: Erlangga.

Sarwono, Sarlito Wirawan. 2010. Psikologi Remaja. Jakarta: Rajawali Press.

Setiadi, Elly M. 2011. Pengantar Sosiologi: Pemahaman Fakta dan Gejala Permasalahan Sosial: Teori, Aplikasi dan Pemecahannya. Jakarta: Kencana.

Setyo, Anisa Pratiwi dan Notobroto, Hari Basuki. 2013. "Faktor yang Berhubungan dengan Perilaku Seksual Pranikah Remaja Komunitas Pemulung di Kota Surabaya". Jurnal Biometrika dan Kependudukan, Vol. 2, No. 1 Juli 2013: 10-17.

Soetjiningsih. 2004. Tumbuh Kembang Remaja dan Permasalahannya. Jakarta: CV Sagung Seto.

Suparmi. 2015. "Pengaruh Keharmonisan Keluarga terhadap Perilaku Seksual Berisiko Remaja di Wilayah Perkotaan Indonesia". Jurnal Widyariset, Volume 18, Nomor 1, April 2015, 127-134.

Suparmi dan Siti Isfandari. 2016. "Peran Teman Sebaya terhadap Perilaku Seksual Pranikah pada Remaja Laki-Laki dan Perempuan di Indonesia". Buletin Penelitian Kesehatan, Vol. 44, No. 2, Juni 2016 : 139 - 146.

Suwarni, Linda. 2009. "Monitoring Parental dan Perilaku Teman Sebaya Terhadap Perilaku Seksual Remaja SMA di Kota Pontianak". Jurnal Promosi Kesehatan Indonesia, Vol. 4, No. 2: 127-133.

Widyastuti, E.S. 2009. "Personal dan Sosial yang Memengaruhi Sikap Remaja terhadap Hubungan Seks Pranikah". Jurnal Promosi Kesehatan Indonesia, Vol. 4 No. 2: 75-85. Yudistira. 1997. Penegakan Hukum Lingkungan Hidup. Jakarta: Restu Agung. 